\title{
Penicillin treatment of gonorrhoea in Edinburgh
}

\author{
R. N. T. THIN \\ Royal Infirmary, Edinburgh EH3 $9 Y W$
}

Since its introduction, penicillin has been the treatment of choice for gonorrhoea. However, in recent years, there has been concern over the increasing proportion of strains of Neisseria gonorrhoeae showing diminished sensitivity to this drug (British Medical fournal, 1972). The proportion of such strains varies from place to place, and from time to time in the same place (British Medical fournal, 1972).

The presence of gonococci with decreased sensitivity to penicillin is of special importance in places where there are many visitors. Edinburgh is such a place and this paper reports results of penicillin treatment in this city in 1972.

\section{Methods}

In male cases, diagnosis of urethral gonorrhoea was based on results of Gram-stained smears and/or cultures. All patients who relapsed had positive culture results before and after treatment. Male patients with rectal gonorrhoea were not included.

In female cases, smears for Gram-staining were made at the first and subsequent visits but the diagnosis of gonorrhoea was based on the results of cultures taken from the urethra, cervix, and rectum. Material for culture was plated directly on to Columbia agar base (Ellner, Stoessel, Drakeford, and Vasi, 1966) enriched with 15 per cent. heated human blood plus vancomycin and colistin (Thayer and Martin, 1966). Neisseria gonorrhoeae was identified by colonial appearance, oxidase reaction, and results of sugar fermentation tests.

During the first half of the year, treatment consisted of one injection of $5 \mathrm{~m}$.u. benzyl penicillin made up in $8 \mathrm{ml}$. of 0.5 per cent. lignocaine. During the second half, $1 \mathrm{~g}$. probenecid was given orally 15 minutes before the same dose of penicillin.

Patients were asked to attend 3 days, 1 week, 2 weeks, 4 weeks, and 12 weeks after treatment.

Male patients were asked to refrain from micturition for 3 hours before attending. At each visit they were examined clinically. Any urethral discharge obtained after massaging the urethra from bulb to meatus was examined by Gramstain and culture. Urine was examined by the two-glass

Received for publication May 15, 1973

Present address: Special Treatment Centre, St. Bartholomew's Hospital, London, E.C.1 test. From the second week, any man without a discharge but with threads in the urine, was asked to attend again after holding his urine overnight for smear and culture examination. Patients who developed non-gonococcal urethritis $\mathbf{1 5}$ or more days after treatment for gonorrhoea (post-gonococcal urethritis) were given $250 \mathrm{mg}$. tetracycline four times daily for 5 days.

Penicillin sensitivity tests were carried out by the discdiffusion method using individually impregnated discs containing 1 unit penicillin prepared in the hospital laboratory (Gould and Bowie, 1952). Results were reported as minimum inhibitory concentrations (MIC) after relating the diameter of the zone of inhibition to the MIC using a graph described by Gould and Bowie (1952). The method did not distinguish between individual sensitive strains, but these were all strains requiring less than $0 \cdot 1$ unit penicillin per $\mathrm{ml}$.

In distinguishing relapse from re-infection, the suggestion of Evans (1966) was followed; namely, if gonococci reappear within 14 days of treatment and if the patient denies further intercourse, the infection is considered to have relapsed; all other recurrences are considered to be due to re-infection.

\section{Results}

During the year, 809 cases were treated with penicillin. The age distribution is shown in Table $I$ and the countries of origin in Table II (overleaf).

TABLE I Age distribution

\begin{tabular}{|c|c|c|c|c|}
\hline \multirow[b]{2}{*}{ Age group (yrs) } & \multicolumn{2}{|c|}{ Men } & \multicolumn{2}{|c|}{ Women } \\
\hline & No. & Per cent. & No. & Per cent. \\
\hline $\begin{array}{r}0-14 \\
15-19 \\
20-24 \\
25-29 \\
30-34 \\
35-39 \\
40-44 \\
45+\end{array}$ & $\begin{array}{r}0 \\
86 \\
215 \\
103 \\
59 \\
18 \\
14 \\
14\end{array}$ & $\begin{array}{r}16.8 \\
42.3 \\
20.4 \\
11.6 \\
3.5 \\
2.7 \\
2.7\end{array}$ & $\begin{array}{r}1 \\
97 \\
126 \\
42 \\
21 \\
6 \\
3 \\
4\end{array}$ & $\begin{array}{r}0 \cdot 3 \\
32 \cdot 3 \\
42 \cdot 1 \\
14 \cdot 0 \\
7 \cdot 0 \\
2 \cdot 0 \\
1 \cdot 0 \\
1 \cdot 3\end{array}$ \\
\hline Total & 509 & $100 \cdot 0$ & 300 & $100 \cdot 0$ \\
\hline
\end{tabular}

In Group 1, given 5 m.u. benzyl penicillin, 369 cases were treated; 241 were followed for 2 weeks or more and seventeen ( 7 per cent.) of these relapsed (Table III). 
TABLE II Country of origin

\begin{tabular}{|c|c|c|c|c|}
\hline \multirow[b]{2}{*}{ Country } & \multicolumn{2}{|l|}{ Men } & \multicolumn{2}{|c|}{ Women } \\
\hline & No. & Per cent. & No. & Per cent. \\
\hline $\begin{array}{l}\text { United Kingdom and } \\
\text { Eire }\end{array}$ & 450 & 88.4 & 267 & $89 \cdot 0$ \\
\hline Caribbean & 4 & 0.8 & 0 & \\
\hline Africa & 5 & $1 \cdot 0$ & 3 & 1.0 \\
\hline Asia & 24 & $4 \cdot 7$ & 3 & 1.0 \\
\hline Europe & 10 & $2 \cdot 0$ & 12 & $4 \cdot 0$ \\
\hline Other & 16 & $3 \cdot 1$ & 15 & $5 \cdot 0$ \\
\hline Total & 509 & $100 \cdot 0$ & 300 & $100 \cdot 0$ \\
\hline
\end{tabular}

TABLE III Results in Group 1 treated with 5 m.u. benzyl penicillin, by sex

\begin{tabular}{|c|c|c|c|c|}
\hline \multirow[b]{2}{*}{ Sex } & \multirow{2}{*}{$\begin{array}{l}\text { No. } \\
\text { treated }\end{array}$} & \multirow{2}{*}{$\begin{array}{l}\text { No. followed } 2 \text { wks } \\
\text { or more }\end{array}$} & \multicolumn{2}{|c|}{ Relapses } \\
\hline & & & No. & Per cent. \\
\hline $\begin{array}{l}\text { Men } \\
\text { Women }\end{array}$ & $\begin{array}{l}235 \\
134\end{array}$ & $\begin{array}{r}154 \\
87\end{array}$ & $\begin{array}{r}12 \\
5\end{array}$ & $\begin{array}{l}7 \cdot 8 \\
5 \cdot 7\end{array}$ \\
\hline Total & 369 & 241 & 17 & $7 \cdot 0$ \\
\hline
\end{tabular}

In Group 2, given $1 \mathrm{~g}$. probenecid in addition to 5 m.u. benzyl penicillin, 440 cases were treated; 286 were followed for 2 weeks or more and five (1.7 per cent.) of these relapsed (Table IV). The penicillin sensitivity of strains of gonococci isolated from patients who relapsed is shown in Table V.

TABLE IV Results in Group 2 treated with $1 \mathrm{~g}$. probenecid and 5 m.u. benzyl penicillin, by sex

\begin{tabular}{|c|c|c|c|c|}
\hline \multirow[b]{2}{*}{$\operatorname{Sex}$} & \multirow{2}{*}{$\begin{array}{l}\text { No. } \\
\text { treated }\end{array}$} & \multirow{2}{*}{$\begin{array}{l}\text { No. followed } 2 \text { weeks } \\
\text { or more }\end{array}$} & \multicolumn{2}{|c|}{ Relapse } \\
\hline & & & No. & Per cent. \\
\hline $\begin{array}{l}\text { Men } \\
\text { Women }\end{array}$ & $\begin{array}{l}274 \\
166\end{array}$ & $\begin{array}{r}191 \\
95\end{array}$ & $\begin{array}{l}4 \\
1\end{array}$ & $\begin{array}{l}2 \cdot 1 \\
1 \cdot 0\end{array}$ \\
\hline Total & 440 & 286 & 5 & $1 \cdot 7$ \\
\hline
\end{tabular}

TABLE V Penicillin sensitivities in cases with relapse

\begin{tabular}{|c|c|c|c|c|}
\hline Group & 1 & & 2 & \\
\hline Sex & Men & Women & Men & Women \\
\hline $\begin{array}{l}\text { No. of relapses in } \\
\text { cases with sensitive } \\
\text { strains } \\
\text { Cases with sensitive } \\
\text { strains } \\
\text { Relapse rate (per } \\
\text { cent.) }\end{array}$ & $\begin{array}{r}4 \\
114 \\
3.5\end{array}$ & $\begin{array}{c}1 \\
60 \\
1 \cdot 7\end{array}$ & $\begin{array}{r}1 \\
141 \\
0.7\end{array}$ & $\begin{array}{c}1 \\
67 \\
1.5\end{array}$ \\
\hline $\begin{array}{l}\text { No. of relapses in } \\
\text { cases with diminished } \\
\text { sensitivity } \\
\text { Cases with diminished } \\
\text { sensitivity } \\
\text { Relapse rate (per } \\
\text { cent. }\end{array}$ & $\begin{array}{c}8 \\
40 \\
20 \cdot 0\end{array}$ & $\begin{array}{c}4 \\
27 \\
14 \cdot 8\end{array}$ & $\begin{array}{c}3 \\
50 \\
6.0\end{array}$ & $\begin{array}{c}0 \\
28 \\
0.0\end{array}$ \\
\hline
\end{tabular}

aiminished sensitivity MIC $\geqq 0.1$ units per $\mathrm{ml}$.
When all cases with positive culture results are considered, $25 \cdot 7$ per cent. showed diminished sensitivity to penicillin (Table VI). Among cases with infection thought to originate in Edinburgh, 29.1 per cent. showed diminished sensitivity, compared with 17.5 per cent. among infections originating outside Edinburgh.

TABLE VI Penicillin sensitivities among strains of gonococcus from inside and outside Edinburgh

\begin{tabular}{|c|c|c|c|}
\hline \multirow[b]{2}{*}{ Place of isolation of strains } & \multirow[b]{2}{*}{ Total no. } & \multicolumn{2}{|c|}{$\begin{array}{l}\text { Strains with } \\
\text { diminished sensitivity }\end{array}$} \\
\hline & & No. & Per cent. \\
\hline $\begin{array}{l}\text { Within Edinburgh } \\
\text { Outside Edinburgh }\end{array}$ & $\begin{array}{l}570 \\
234\end{array}$ & $\begin{array}{r}166 \\
41\end{array}$ & $\begin{array}{l}29 \cdot 1 \\
17 \cdot 5\end{array}$ \\
\hline Total & 804 & 207 & $25 \cdot 7$ \\
\hline
\end{tabular}

To assess the reliability of the quantitative penicillin sensitivity tests in vitro, the results in the cases of 208 pairs of sexual partners were compared (Table VII). In each case it was considered that the infecting intercourse had taken place within the 21 days preceding examination of both partners. In 131 couples both partners were reported as having sensitive strains, and in twelve more couples both partners had strains with diminished sensitivity at the same MIC. Within the limitations of the method, there was thus agreement among 143 couples (68.8 per cent.).

TABLE VII Correlation of penicillin sensitivity in pairs of sexual partners

\begin{tabular}{|c|c|c|}
\hline Pencillin sensitivity & No. & Per cent. \\
\hline $\begin{array}{l}\text { Sensitive strains in both partners } \\
\text { Both with diminished sensitivity at same level } \\
\text { Difference of } 1 \text { or } 2 \text { dilutions } \\
\text { Difference of more than } 2 \text { dilutions }\end{array}$ & $\begin{array}{r}131 \\
12 \\
32 \\
33\end{array}$ & $\begin{array}{r}63 \cdot 0 \\
5 \cdot 8 \\
15 \cdot 4 \\
15 \cdot 8\end{array}$ \\
\hline ot: & 208 & $100 \cdot 0$ \\
\hline
\end{tabular}

Among men, recurrence of gonorrhoea after treatment was considered to be due to re-infection in 23 cases; in four cases re-infection occurred during the 14 days after treatment. Among women, fourteen cases of recurrence were classified as re-infections; in one case this occurred during the first 14 days.

TABLE VIII Details of follow-up

\begin{tabular}{|c|c|c|c|c|c|}
\hline \multirow[b]{2}{*}{ Group } & \multirow[b]{2}{*}{$\operatorname{Sex}$} & \multirow[b]{2}{*}{ No. treated } & \multicolumn{3}{|c|}{ No. followed for } \\
\hline & & & 3 days & $2 w k s$ & 3 mths \\
\hline 1 & $\begin{array}{l}\text { Male } \\
\text { Female }\end{array}$ & $\begin{array}{l}235 \\
134\end{array}$ & $\begin{array}{r}195 \\
95\end{array}$ & $\begin{array}{r}154 \\
87\end{array}$ & $\begin{array}{l}84 \\
41\end{array}$ \\
\hline 2 & $\begin{array}{l}\text { Male } \\
\text { Female }\end{array}$ & $\begin{array}{l}274 \\
166\end{array}$ & $\begin{array}{l}240 \\
117\end{array}$ & $\begin{array}{r}191 \\
95\end{array}$ & $\begin{array}{r}104 \\
42\end{array}$ \\
\hline
\end{tabular}


Post-gonococcal urethritis was diagnosed in forty men in Group 1 and 78 men in Group 2. Some details of follow-up are shown in Table VIII. Half of the men had held their urine for 3 hours or more before examination.

\section{Discussion}

Reduction in the overall failure rate from 7 to 1.7 per cent. by giving probenecid in addition to penicillin appears to be satisfactory. However, only 25.7 per cent. of strains of Neisseria gonorrhoeae isolated from these cases were reported as showing diminished sensitivity to penicillin. Gray, Phillips, and Nicol (1970), using the same dose of probenecid and penicillin, reported a failure rate of 0.5 per cent. in London; 35 per cent. of strains isolated from their cases showed diminished sensitivity to penicillin. Furthermore, in an area where 85 per cent. of strains of gonococci showed diminished sensitivity to penicillin, Thin (1973) reported a failure rate of 1.3 per cent. with the same regime. Strict comparison between these series is not valid, because of variations in methods, and with few cases relapsing, a difference of one or two cases greatly alters the percentage.

One possible explanation for the lower incidence of less sensitive strains might be the insensitivity in vitro of the penicillin sensitivity tests. However, correlation of results between sexual partners appeared reasonable. Comparison with the plate-dilution method is made periodically and agreement has always been good. During 1972, several strains were examined by both methods and the results were identical. The disc-diffusion method is less timeconsuming than either the plate-dilution or the tube-dilution methods, but it requires uniformity of technique as emphasized by Ericsson (1960). This appears to have been achieved here. Problems such as indefinite zone margin, growth within zones of inhibition (Reyn, Korner, and Bentzon 1958), and wide scatter of zone diameters corresponding to MICs (Jokipii and Renkonen, 1970), did not occur during this series.

The difference in the proportion of strains with diminished sensitivity originating inside and outside Edinburgh is curious. The sources of the latter were widely scattered, but they were mainly from the United Kingdom.

It appears reasonable to conclude that a case of gonorrhoea infected in Edinburgh will have about a 30 per cent. chance of harbouring a strain of gonococcus with diminished sensitivity to penicillin, and that $1 \mathrm{~g}$. probenecid plus $5 \mathrm{~m}$.u. benzyl penicillin is at present a satisfactory treatment.

\section{Summary}

Edinburgh attracts many visitors. It was therefore considered worthwhile to report the results of penicillin treatment of gonorrhoea in Edinburgh, and the incidence of diminished sensitivity to penicillin among the strains of gonococci isolated. Of 241 male and female cases treated with 5 m.u. benzyl penicillin and followed up for at least 2 weeks after treatment, seventeen ( 7 per cent.) relapsed. Of 286 cases treated with 1 g. probenecid and 5 m.u. benzyl penicillin, $5(1.7$ per cent.) relapsed.

A disc-diffusion method was used for quantitative penicillin sensitivity estimations in vitro. Results in 208 pairs of sexual partners were compared, and in 143 couples (68.8 per cent.) the results were the same in both partners. In some strains tests using the disc-diffusion and plate-dilution method were carried out together and the results were the same. It is concluded that the disc-diffusion method as used here is reasonably reliable.

Overall, $25 \cdot 7$ per cent. of cases were reported as showing diminished sensitivity to penicillin. The figure for infections originating in Edinburgh was 29.1 per cent., and for those outside Edinburgh it was $17 \cdot 5$ per cent.

I thank Dr. D. H. H. Robertson and Dr. M. Taylor Brown for permission to include patients under their care. I also thank Prof. B. P. Marmion and his colleagues for the microbiological studies.

\section{References}

British Medical fournal (1972) 2, 421

Ellner, P. D., Stoessel, C. J., Drakeford, E., and VasI, F. (1966) Amer. f. clin. Path., 45, 502

ERIcsson, H. (1960) Scand. F. clin. lab. Invest., 12, 408

Evans, A. J. (1966) Brit. F. vener. Dis., 42, 251

Gould, J. C., and BowIE, J. H. (1952) Edin. med. F., 59, 178

Gray, R. C. F., Phillips, I., and Nicol, C. S. (1970) Brit. F. vener. Dis., 46, 401

JokIPII, A. M. M., and RENKonen, O. V. (1970) Chemotherapy (Basel), 15, 317

ReYN, A., Korner, B., and Bentzon, M. W. (1958) Brit. F. vener. Dis., 34, 227

ThaYeR, J. D., and MARTIN, J. E. (1966) Publ. Hlth Rep. (Wash.), 81, 559

ThIN, R. N. T. (1973) Brit. f. vener. Dis., 49, 216

La pénicilline dans le traitement de la gonococcie à Edimbourg

SOMMAIRE

Edimbourg attire beaucoup de visiteurs; on considère donc utile de rapporter les résultats du traitement de la 
gonococcie par la pénicilline à Edimbourg et l'incidence d'une diminution de la sensibilité à cet antibiotique parmi les souches de gonocoques isolées. Sur 241 cas masculins et féminins traités par $5 \mathrm{~m} . \mathrm{u}$. de benzylpénicilline et suivis au moins deux semaines après traitement, il y eut 17 rechutes ( 7 pour cent). Sur 286 cas traités avec $1 \mathrm{~g}$ de probénécide et $5 \mathrm{~m}$.u. de benzylpénicilline, il y eut 5 rechutes ( 1,7 pour cent).

La méthode de diffusion à partir de disques a été employée pour estimer quantitativement, in vitro, la sensibilité à la pénicilline. Pour 208 paires de partenaires sexuels, les résultats furent comparés; pour 143 couples
(68,8 pour cent) les résultats furent les mêmes chez les deux partenaires. Pour quelques souches, la méthode des disques et la méthode des dilutions en boîte furent pratiquées en même temps et les résultats furent identiques. On conclut que l'on peut accorder une confiance raisonnable à la méthode de diffusion à partir de disques telle qu'elle est utilisée ici.

Dans l'ensemble, on enregistra 25,7 pour cent de cas montrant une sensibilité diminuée à la pénicilline. Le chiffre pour les infections contractées à Edimbourg fut de 29,1 pour cent et de 17,5 pour cent pour celles contractées en dehors d'Edimbourg. 